\title{
KAJIAN PENGGUNAAN ANTIBIOTIK PADA KOMODITAS PERKEBUNAN
}

\section{REVIEW ON THE USING OF ANTIBIOTICS ON PLANTATION COMMODITIES}

\author{
Farriza Diyasti*, Eva Lizarmi \\ Direktorat Perlindungan Perkebunan - Direktorat Jenderal Perkebunan, \\ Kampus Kementerian Pertanian \\ Jl. Harsono RM No. 03, Gedung C, Pasar Minggu, Jakarta 12550 - Indonesia \\ *Korespondensi: riza.diyasti@gmail.com
}

\begin{abstract}
ABSTRAK
Resistensi antimikroba (Antimicrobial Resistence/AMR) telah menjadi isu global yang mengkhawatirkan kesehatan masyarakat. Selain disebabkan penggunaan obat-obatan pada manusia dan hewan, pengaplikasian bakterisida yang mengandung antibiotik juga mengambil peran terjadinya AMR ini. Khusus pada komoditas perkebunan, diperoleh informasi penyakit yang disebabkan oleh bakteri umumnya berasal dari kelompok Ralstoniaceae. Data penggunaan bahan pengendali berupa bakterisida yang mengandung antibiotik di lapangan masih sangat terbatas, sehingga menjadi kendala pemangku kepentingan dalam mengambil kebijakan terkait penggunaan antibiotik ini. Tulisan ini bertujuan mengkaji penggunaan antibiotik pada komoditas perkebunan dengan mengumpulkan dan menelaah informasi dari berbagai sumber. Berdasarkan data yang terhimpun, penggunaan antibiotik dalam mengendalikan penyakit bakteri pada komoditas perkebunan masih pada kategori risiko rendah, dan telah lama tidak direkomendasikan lagi sejak diterapkannya Gerakan Pengendalian Hama Terpadu (PHT) pada tahun 2018, dengan mengkombinasikan beberapa teknik pengendalian yang ramah lingkungan. Namun tindakan pengawasan tetap harus dilakukan secara ketat di lapangan untuk menghindari terjadinya resistensi antibiotik yang berdampak buruk bagi lingkungan.
\end{abstract}

Kata kunci: antimicrobial; bakterisida; PHT; ralstonia; resistensi

\begin{abstract}
Antimicrobial resistance (AMR) has become a global issue that worries public health. Besides being caused by the use of drugs in humans and animals, the application of bactericides containing antibiotics also played a role in the emergence of AMR. Particularly for plantation commodities, information on diseases caused by bacteria generally comes from the Ralstoniaceae group. Data on the use of control agents in the form of bactericides containing antibiotics in the field is still very limited, so that it becomes an obstacle for stakeholders in making policies regarding the use of these antibiotics. This paper aims to examine the use of antibiotics in plantation crops by collecting and analyzing information from various sources. Based on the data collected, the use of antibiotics in controlling bacterial diseases in plantation commodities is still at a low risk category, and has long been abandoned since the implementation of the Integrated Pest Control (IPM) movement in 2018, by combining several environmentally friendly control techniques. However, surveillance measures must still be carried out strictly in the field to avoid the occurrence of antibiotic resistance which has a negative impact on the environment.
\end{abstract}

Keywords: anrimicrobial; bactericides; IPM; ralstonia; resistance

\section{PENDAHULUAN}

Serangan penyakit pada tanaman

merupakan faktor pembatas peningkatan produksi dan ekspor produk ke pasar

global. Terlebih lagi penyakit tanaman yang disebabkan oleh bakteri karena 
dapat berkembang dengan cepat, menyebabkan kelayuan bahkan terjadi proses pembusukan pada komoditas pertanian tersebut. Pestisida berbahan aktif antibiotik merupakan senyawa kimia yang diklaim efektif mengatasi penyakit bakteri pada tanaman. Namun, penggunaan antibiotik ini menimbulkan kontroversial karena dapat menimbulkan resistensi dan dampak buruk bagi lingkungan. Munculnya strain bakteri resisten terhadap antibiotik telah membatasi efektivitas antibiotik tersebut dalam bidang medik maupun pengendalian penyakit pada tanaman (Raini, 2015).

Isu terjadinya resistensi antibiotik tidak hanya berkembang di Indonesia tapi juga secara global yang menjadi satu persoalan cukup pelik dan harus segera diatasi. Resistensi antibiotik menyebabkan penurunan kemampuan antibiotik tersebut dalam mengobati infeksi dan penyakit pada manusia, hewan dan tumbuhan, sehingga berdampak pada peningkatan angka penyakit, biaya, dan efek samping terhadap penggunaan antibiotik ini (KEMENKES, 2015). Badan Kesehatan Dunia (World Health Organization/WHO) menunjukkan bahwa Asia Tenggara memiliki angka tertinggi dalam kasus resistensi antibotik di dunia (Taylor \& Reeder, 2020). Namun kepastian angka penggunaan antibiotik di bidang pertanian belum dapat diperoleh karena keterbatasan data lapangan. Beberapa pandangan terkait penggunaan antibiotik ini antara lain McManus (2014) memperkirakan penggunaan antibiotik pada tanaman masih tergolong rendah, berkisar 0,26 dan 0,5\%. Namun dikutip dari O'Neill (2015) yang mengambil data dari Wellcome Trust memperkirakan penggunaan di bidang pertanian antara 63ribu-240ribu ton tahun ${ }^{-1}$. Menurut Jacobs (2019), penggunaan streptomycin pada tanaman jeruk di Amerika mencapai hingga 292 ton tahun $^{-1}$ yang mencakup antibiotik aminoglikosida, kelas antibiotik yang mencakup Streptomisin. Variasi dan keterbatasan data membuat kesulitan dalam upaya pembatasan dan pengawasan terhadap kejadian resistensi antibiotik. Terlebih lagi data penggunaan antibiotik di Indonesia. Melalui tulisan ini, penulis mencoba mengkaji informasi akan penggunaan antibiotik, khususnya pada komoditas perkebunan.

\section{METODE PENELITIAN}

Tulisan ini disusun menggunakan metode deskriptif untuk mengumpulkan, merumuskan, serta menjelaskan secara rinci dan sistematis mengenai penggunaan antibiotik pada komoditas perkebunan. 
HASIL DAN PEMBAHASAN

\section{Perkembangan penggunaan antibiotik pada tanaman secara global}

Eksplorasi antibiotik untuk mengendalikan penyakit tanaman dimulai pada tahun 1950. Dari sekitar 40 jenis antibiotic yang diteliti, 8 jenis digunakan secara komersial untuk penyakit tanaman. Beberapa pestisida antibiotik yang banyak digunakan di antaranya Streptomisin, Kasugamisim, Blastisidin, Oksitetrasiklin, dan Validamisin (Raini, 2015).

Penggunaan antibiotik pada tanaman mencakup bakterisida dan beberapa fungisida yang mengandung antibiotik di dalamnya. Penggunaan antibiotik pada bakterisida dan fungisida dirasa cukup efektif karena karakteristik serangan bakteri yang menginfeksi ke dalam jaringan tanaman ini sulit dikendalikan hanya dengan pemangkasan jaringan yang terinfeksi atau pemberian pestisida pada permukaan tanaman tersebut (Raini, 2015). Penyakit yang disebabkan oleh bakteri dapat dengan cepat menjadi wabah dan menyebabkan kerugian besar karena pertumbuhan eksponensial bakteri yang dapat menggandakan diri berkali lipat dalam waktu singkat. Dall (2020) mengungkapkan kasus Xanthomonas campestris pv. yang menyerang pertanaman jeruk menyebabkan pemusnahan tanaman jeruk di negara-negara teluk lebih dari 20 juta pohon. Di samping itu, penggunaannya juga sangat besar pada pertanian jeruk di Florida dan California hingga mencapai 700.000 ha. Menurut Taylor \& Reeder (2020), sebaran penyakit tanaman yang disebabkan oleh bakteri hampir mencapai 5/6 dari total penyakit tanaman yang disebabkan oleh organisme pengganggu tumbuhan (OPT) lainnya di Amerika (Gambar 1). Namun dalam penggunaannya, Asia Tenggara merupakan negara terbesar dalam penggunaan antibiotik jenis Streptomisin, Tetrasiklin, dan Kasugamisin (Tabel 1).

Taylor \& Reeder (2020) juga menginformasikan $7.4 \%$ beras di Asia Tenggara mengandung antibiotik. Sedangkan Amerika menempati urutan ke-2 dalam penggunaan antibiotik dengan jenis Kasugamisin, Oksitetrasiklin, dan Cefahedroxil.



Gambar 1. Proporsi serangan penyakit tumbuhan akibat OPT di seluruh belahan dunia (Taylor \& Reeder, 2020)

Beberapa jenis antibiotik lainnya dilaporkan Wan et al. (2019) yaitu 
penggunaan Gentamisin di Meksiko dan Kosta Rika, Asam Oksonilat di Israel, serta Kasugamisin di Jepang dan negaranegara Asia lainnya, namun dengan data yang masih sangat terbatas. Selain dengan target utama bakteri, tidak jarang antibiotik ini juga digunakan untuk mengendalikan cendawan, serangga, dan tungau (Taylor \& Reeder, 2020). Serangan OPT ini diduga memicu serangan sekunder bakteri akibat pelukaan yang ditimbulkan, sehingga bakteri dapat mudah masuk menginfeksi ke dalam jaringan tanaman tersebut. Hal ini menimbulkan kekhawatiran karena penggunaan antibiotik yang berlebihan dan tidak tepat sasaran dapat berdampak buruk bagi kesehatan manusia dan lingkungan apabila terjadi resistensi antibiotik tersebut.

Tabel 1. Jenis antibiotik yang banyak digunakan pada beberapa daerah

\begin{tabular}{ccccc}
\hline \multirow{2}{*}{ Jenis antibiotik } & \multicolumn{4}{c}{ Wilayah } \\
\cline { 2 - 5 } & Amerika & Mediterania Timur & Asia Tenggara & Pasifik Barat \\
\hline Kasugamisin & 187 & 13 & 253 & 157 \\
Streptomisin & 6 & 28 & 765 & 27 \\
Tetrasiklin & 2 & 1 & 627 & 0 \\
Oksitetrasiklin & 41 & 2 & 6 & 44 \\
Gentamisin & 8 & 0 & 0 & 31 \\
Ningnanmisin & 0 & 0 & 0 & 35 \\
Oksonilik acid & 0 & 0 & 0 & 158 \\
Validamisin & 0 & 0 & 0 & 2 \\
Cefadroxil & 19 & 0 & 0 & 0 \\
Amoxicilin & 0 & 8 & 0 & 0 \\
Aerofungin & 0 & 0 & 14 & 0 \\
\hline
\end{tabular}

Sumber: Taylor \& Reeder (2020).

\section{Codex \\ Alimentarius}

mendefinisikan antimicrobial resistence (AMR) sebagai kemampuan mikroorganisme untuk berkembang biak atau bertahan dalam peningkatan kadar antimikroba, sehingga tidak efektif lagi dikendalikan oleh antimikroba yang sama (FAO \& WHO, 2015).

(2012) keterbatasan data terhadap penggunaan antibiotik pada tanaman dan pengaruhnya pada manusia bahkan lingkungan membuat harus semakin waspada terhadap penggunaannya. Hal tersebut akan mengakibatkan terjadinya suatu kasus resistensi antibiotik pada suatu populasi penyakit tumbuhan akibat perpindahan gen secara horizontal (Horizontal Gene Transfer/HGT) dari mikroorganisme epifit lainnya (Gambar 2).

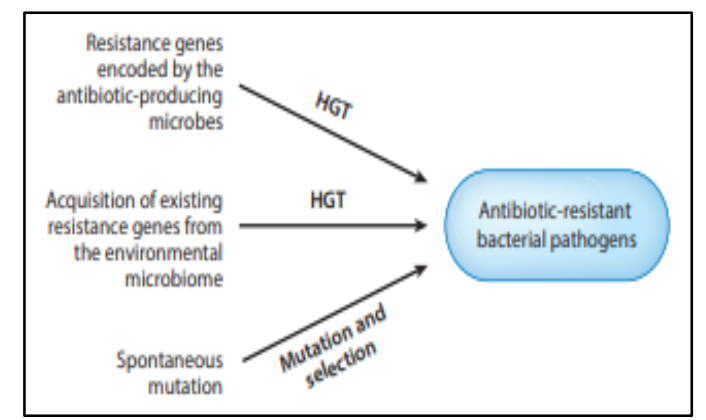

Gambar 2. Ilustrasi skema resistensi pathogen mikroba (Sudin \& Wang, 2018) 
Hal ini sejalan dengan ditemukannya resistensi gen antibiotik dengan plasmid identik berspektrum luas pada penyakit manusia maupun tanaman (Sundin \& Wang, 2019). Menurut Utami (2012) Resistensi mikroorganisme terhadap antibiotik dapat terjadi karena beberapa hal, antara lain:

1. Adanya mikroorganisme yang menghasilkan enzim yang dapat merusak aktivitas obat

2. Terjadinya perubahan kondisi permeabilitas dari mikroorganisme

3. Adanya modifikasi reseptor site pada bakteri sehingga menyebabkan afinitas obat berkurang

4. Terjadi mutasi dan transfer genetik. Resistensi bakteri terhadap antibiotik biasanya terjadi karena adanya perubahan genetik dan diikuti dengan serangkaian proses seleksi oleh antibiotik yang diberikan. Dengan demikian akan terbentuk bakteri dengan daya tahan lebih tinggi. Hal ini terjadi dikarenakan penggunaan antibiotik yang sama berulang-ulang dan tidak terkendali (irasional). Penggunaan pestisida dengan antibiotik termasuk penggunaan herbisida dapat menyebabkan resistensi antibiotik hingga 100 ribu kali lebih cepat (Kurenbach et al., 2018).

Belum diketahui secara pasti mekanisme penularan resistensi antibiotik dari tumbuhan ke manusia maupun hewan. Sundin \& Wang (2019) menggambarkan ilustrasi penyebaran dan penularan antibiotik dari tanaman ke lingkungan yaitu dengan diawali dari pengaplikasian pestisida yang mengandung antibiotik pada permukaan tanaman, kemudian droplet membasahi kanopi tanaman dan tanah. Tanah yang terinfestasi antibiotik memengaruhi kehidupan mikrobiota tanah, dan berdampak pada hewan ternak yang mengonsumsi hijauan di sekitar pertanaman, hal yang sama juga memengaruhi kehidupan makhluk hidup lainnya baik langsung maupun tidak langsung (Gambar 3). Sebanyak 44-71\% larutan semprot yang digunakan dalam pengaplikasian pestisida hilang ke udara dan lingkungan (Sundin \& Wang, 2019). Adanya dugaan bahwa konsumsi langsung produk tumbuhan mentah lebih meningkatkan risiko resistensi antibiotik ke manusia (FAO \& WHO, 2019). Hal yang sama dikemukakan oleh Taylor \& Reeder (2020) tanaman yang dikonsumsi langsung, dapat menjadi media penularan bakteri resisten untuk memasuki usus manusia. Untuk komoditas perkebunan yang tidak dikonsumsi secara langsung, melainkan melalui beberapa pengolahan terlebih dahulu sebelum masuk ke dalam tubuh manusia diduga memiliki risiko yang lebih rendah. 


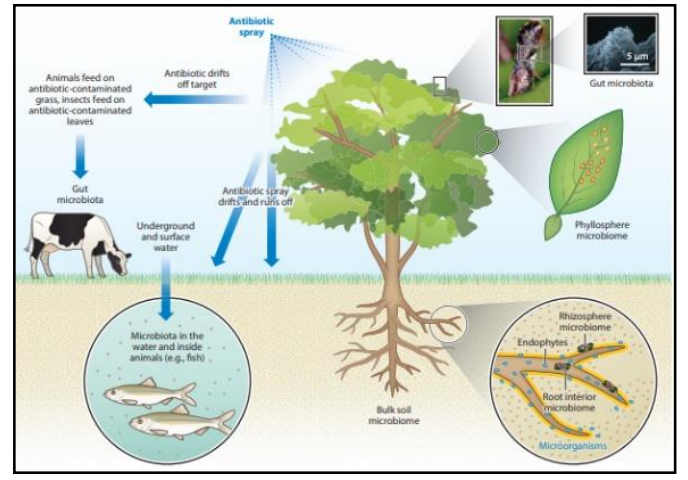

Gambar 3. Ilustrasi penyebaran dan penularan antibiotik ke lingkungan (Sundin \& Wang, 2019)

Jenis antibiotik yang banyak digunakan untuk mengendalikan bakteri pada tanaman yaitu Streptomisin dan Oksitetrasiklin. Streptomisin bersifat bakterisid, bekerja dengan mengikat secara irreversibel ribosom bakteri dan menghambat sintesa protein. Pada kadar tinggi, Streptomisin dapat bersifat fitotoksik pada tanaman, oleh karena itu penggunaannya cukup pada permukaan tanaman dan tidak diinjeksikan (Raini, 2015), sedangkan Oksitetrasiklin bersifat bakteriostatik, tidak membunuh bakteri patogen yang ada dalam populasi sehingga kurang efektif jika dibandingkan dengan Streptomisin. Antibiotik ini bekerja dengan menghambat perkembang biakan sel-sel bakteri dengan mengikat secara reversible ribosom bakteri dan menghambat sintesa protein (Stockwell \& Duffy, 2012). Raini (2015) memaparkan bahwa walaupun Streptomisin, Oksitetrasiklin, dan Kasugamisin tidak bersifat karsinogenik namun memiliki efek samping yang cukup serius, seperti reaksi alergi, hipotensi, nyeri perut, dan sebagainya (Tabel 2).

Tabel 2. Karakteristik dan toksisitas antibiotik

\begin{tabular}{|c|c|c|c|}
\hline Jenis & Streptomisin & Oksitetrasiklin & Kasugamisin \\
\hline Karakteristik & $\begin{array}{l}\text { Bakterisida, } \\
\text { fungisida }\end{array}$ & $\begin{array}{l}\text { Bakteriostatik, } \\
\text { fungisida }\end{array}$ & Bakteriostatik, fungisida \\
\hline $\begin{array}{l}\text { Batas Maksimum Residu } \\
\text { (BMR) }\end{array}$ & $\begin{array}{l}0,25 \text { ppm (USA); } \\
0,01 \text { ppm (Eropa) }\end{array}$ & $\begin{array}{l}0,35 \mathrm{ppm} ; 0,15 \mathrm{ppm} \\
\text { (anggur) }\end{array}$ & $0,05 \mathrm{ppm}$ \\
\hline Waktu paruh & 5 jam & 9 jam & Tidak tersedia data \\
\hline Tosisitas akut & $\begin{array}{l}<15.000 \mathrm{mg} \mathrm{kg}^{-1} \\
\text { per hari (oral) }\end{array}$ & $\begin{array}{l}<5.200 \mathrm{mg} \mathrm{kg}^{-1} \text { per } \\
\text { hari (oral) }\end{array}$ & $\begin{array}{l}>5.000 \mathrm{mg} \mathrm{kg}^{-1} \text { per hari } \\
\text { (oral) }\end{array}$ \\
\hline Mutagenisitas & Bukan mutagen & Bukan mutagen & Bukan mutagen \\
\hline Karsinogenisitas & $\begin{array}{l}\text { Tidak } \\
\text { menimbulkan } \\
\text { kanker }\end{array}$ & $\begin{array}{l}\text { Tidak menimbulkan } \\
\text { kanker }\end{array}$ & $\begin{array}{l}\text { Tidak menimbulkan } \\
\text { kanker }\end{array}$ \\
\hline Bahaya & Golongan IV & Golongan IV & Golongan IV \\
\hline Efek samping & $\begin{array}{l}\text { Hipotensi, pusing, } \\
\text { mual, kulit } \\
\text { kemerahan, } \\
\text { muntah, alergi } \\
\text { bagi yang sensitif }\end{array}$ & $\begin{array}{l}\text { Nyeri perut, pusing, } \\
\text { hilang rasa, mual, } \\
\text { muntah, } \\
\text { sensitive terhadap } \\
\text { sinar matahari, kulit } \\
\text { kuning, alergi bagi } \\
\text { yang sensitif }\end{array}$ & $\begin{array}{l}\text { Iritasi pada mata dan } \\
\text { kulit (hewan } \\
\text { percobaan), alergi bagi } \\
\text { yang sensitif }\end{array}$ \\
\hline
\end{tabular}


Resistensi terhadap Streptomisin umum terjadi pada Xanthomonas, resistensi ini dapat ditransfer ke manusia atau hewan (Dall, 2020). (RiveroMenendez et al., 2016) menambahkan bahwa penggunaan fungisida Triazol yang digunakan dalam produksi tanaman tidak kalah mengkhawatirkan karena berkontribusi terhadap resistensi antijamur yang dapat menyebabkan penyakit Aspergillosis pada manusia.

\section{Antibiotik pada komoditas perkebunan}

Berdasarkan informasi dari DITJEN PSP (2021), bakterisida yang digunakan untuk mengendalikan penyakit layu bakteri pada komoditas perkebunan yaitu bakterisida dengan bahan aktif antibiotik Streptomisin, dan Oksitetrasiklin, serta campuran tembaga. Berdasarkan data yang dihimpun DITLINBUN (2021) pada Tabel 3, penyakit tanaman perkebunan yang disebabkan bakteri di Indonesia yang menggunakan antibiotik yaitu penyakit Bakteri Pembuluh Kayu Cengkeh (Ralstonia syzygii) dan Layu Bakteri Tembakau (Ralstonia solanacearum). Kedua penyakit ini disebabkan oleh kelompok Ralstoniaceae yang tergolong bakteri gram negatif dengan kisaran inang yang luas dan strain yang bervariasi.

Menurut Rahayu (2015), proses infeksi bakteri terjadi melalui tiga tahap yaitu:

1. kolonisasi bakteri di permukaan akar,

2. infeksi bakteri di bagian korteks, dan infeksi pada sel parenkim diikuti penyebaran bakteri dalam pembuluh xylem. Dari pembuluh xylem bakteri menyebar sistemik ke bagian atas yaitu batang dan daun.

Tabel 3. Penyakit bakteri pada komoditas perkebunan

\begin{tabular}{|c|c|c|c|}
\hline Komoditas & Jenis Penyakit & Mikroba & Jenis Antibiotik \\
\hline Cengkeh & $\begin{array}{l}\text { Bakteri Pembuluh Kayu Cengkeh } \\
\text { (BPKC) }\end{array}$ & Ralstonia Syzygii & $\begin{array}{l}\text { Oksitetrasiklin } \\
\text { (Hariyadi, 2017) }\end{array}$ \\
\hline \multirow[t]{6}{*}{ Tembakau } & Layu Bakteri & Ralstonia solanacearum & Streptomisin \\
\hline & Busuk Batang Berlubang & Erwinia carotovora & Sulfat $\quad 200-500$ \\
\hline & Lanas & Phytophtora nicotianae & ppm 1-1,5gr $\mathrm{l}^{-1}$ \\
\hline & & Nicotianae & atau \\
\hline & & Kasugamicyn & ${ }_{1}^{\text {Kasugamisin } 2 \mathrm{~g} \mathrm{l}^{-}}$ \\
\hline & & & $\begin{array}{l}\text { (Masnilah\&Prada } \\
\text { na, 2019) }\end{array}$ \\
\hline Kelapa Sawit & Busuk Pangkal Pupus & $\begin{array}{l}\text { Erwinia sp., Penicillium, } \\
\text { Phytophtora, } \\
\text { Marasmius, } \\
\text { Pestalotiopsis, } \\
\text { Fusarium, Curvularia }\end{array}$ & - \\
\hline Nilam & Layu Bakteri & Ralstonia solanacearum & - \\
\hline
\end{tabular}


Ralstoniaceae dapat menyerang hampir pada semua fase perkembangan tanaman. Pada tanaman muda biasanya lebih rentan dan cenderung lebih cepat berkembang sehingga tidak jarang petani menggunakannya justru pada fase pembibitan. Seperti yang dilaporkan oleh Raini (2015), penggunaan Oksitetrasiklin ditemukan pada pembibitan tembakau, namun dalam kadar rendah. Data penggunaan bakterisida antibiotik untuk mengendalikan $R$. solanacearum pada tembakau belum diperoleh secara akurat di lapangan. Informasi yang diperoleh dari Pradana (2019), pengendalian penyakit pada tembakau yang disebabkan oleh bakteri dapat menggunakan Streptomisin Sulfat 200500 ppm 1-1,5g L-1 / Kasugamisin 2g L-1.

Berdasarkan data yang dihimpun DITLINBUN (2021), serangan layu bakteri pada tanaman tembakau yang disebabkan oleh $R$. solanacearum mengalami penurunan dari 2018 ke 2019 (Gambar 4). Dalam proses infeksinya, bakteri Ralstoniaceae mengeluarkan eksudat seperti poligakturonase, endoglukanase, dan senyawa toksin (Gambar 5). Deposit senyawa eksopolisakarida yang berlebihan di dalam pembuluh xylem akan menyumbat aliran air dari tanah ke seluruh tanaman sehingga timbul gejala layu. Senyawa ekstraseluler tersebut adalah faktor penentu virulensi atau keganasan Ralstoniaceae (Rahayu, 2015).

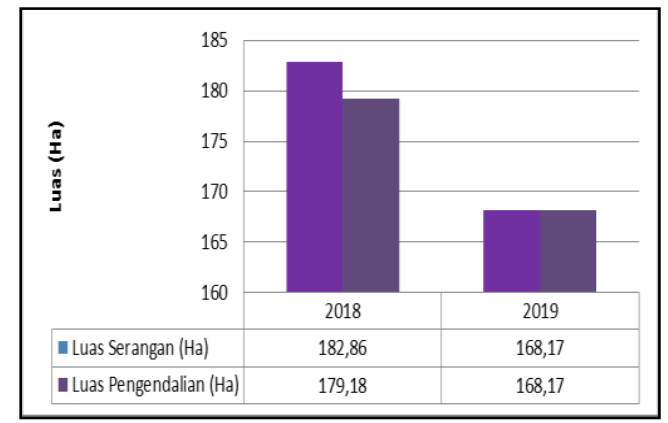

Gambar 4. Perkembangan serangan penyakit layu bakteri tembakau di Indonesia

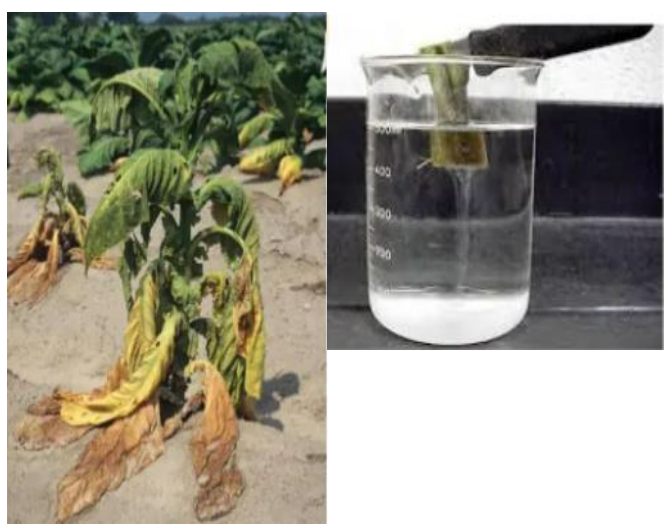

Gambar 5. Gejala layu bakteri pada tembakau (kiri), eksudat bakteri seperti lender pada batang tembakau (kanan) (Masnilah \& Pradana, 2019).

Selain tembakau, komoditas perkebunan yang rentan diserang oleh bakteri yaitu cengkeh. Data yang dihimpun oleh DITLINBUN (2021), serangan Bakteri Pembuluh Kayu Cengkeh (BPKC) yang disebabkan Ralstonia syzygii mengalami fluktuasi dari tahun 2013-2020 (Gambar 6). Pada tahun 2013, serangan BPKC mencapai $2.339,75$ Ha kemudian terus mengalami peningkatan hingga 4.303,24 Ha pada tahun 2015. Pada tahun 2016-2017 serangan BPKC cenderung tidak 
mengalami banyak perubahan hingga tahun 2018 serangan penyakit ini mencapai puncaknya, yaitu mencapai 8.059,41 Ha. Kemudian pada tahun 2019 hanya menurun perlahan sebesar $2 \%$. Pada tahun 2020 serangan BPKC menunjukkan nilai yang cukup melegakan karena turun cukup drastic sebesar 60\% hingga pada angka 3.109,45 Ha.

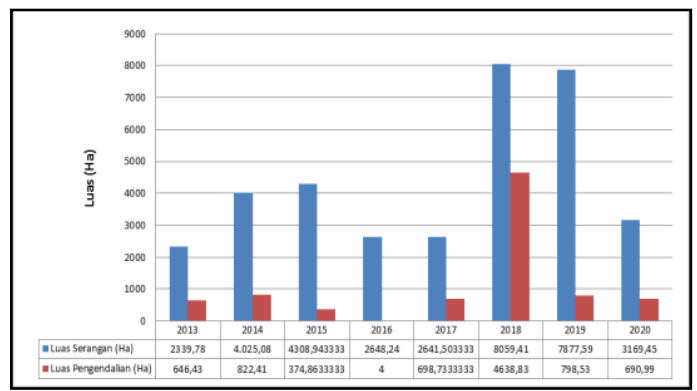

Gambar 6. Perkembangan penyakit BPKC di Indonesia periode tahun 2013-2020

Hidayanti \& Yuniarti (2013) menginformasikan bahwa pada tahun 2013, penyakit BPKC menyerang Kabupaten Jombang, Kediri, Malang, Ngawi, dan Ponorogo dengan intensitas yang cukup tinggi. Hal ini dipengaruhi oleh iklim, kondisi tanah yang kurang baik, miskin hara dan drainase yang buruk. Ditambahkan oleh Hariyadi (2017), saat itu pengendalian BPKC di Jawa Timur masih menggunakan antibiotik jenis Oksitetrasiklin dengan dosis $6 \mathrm{~g} 100 \mathrm{~mL}^{-1}$, dengan interval 3-4 bulan sekali. Selain itu ada juga yang mengkombinasikannya dengan insektisida untuk mengendalikan serangga vektornya. Mardiningsih et al. (2020) menemukan populasi serangga Hindola striata (Hemiptera: Machaerotidae) di sekitar pertanaman cengkeh di Wonogiri dan Karanganyar. Kehadiran $H$. striata dapat berperan sebagai vektor penyebaran dan peningkatan keparahan penyakit BPKC. Gejala serangan yang ditimbulkan oleh $P$. syzygii ditandai dengan menguningnya daun yang kemudian berguguran, ranting-ranting dan cabang mati diikuti layu mendadak (Gambar 7). Kematian tanaman cengkeh akibat penyakit ini dapat berlangsung cepat yaitu antara 312 bulan atau lambat yaitu antara 1-6 tahun, dengan potensi kehilangan hasil mencapai 10 - 15\%. Selain karena vektor, penularan penyakit ini dapat juga melalui alat-alat pertanian seperti golok, gergaji, sabit yang digunakan untuk memotong pohon yang sakit.

Hariyadi (2017) menyampaikan bahwa BPKC merupakan salah satu spesies yang termasuk dalam daftar cegah tangkal Organisme Pengganggu Tanaman Karantina (OPTK) berdasarkan Keputusan Menteri Pertanian No.38/Kpts/HK.060/1/2006. Spesies bakteri ini termasuk OPTK kategori A2.

Perkembangan informasi setelah tahun 2013 belum diperoleh secara akurat di lapangan, namun pada tahun 2018 diadakan kegiatan dan sosialisasi kegiatan gerakan pengendalian penyakit 
perkebunan melalui komponen pengendalian hama terpadu (PHT), sehingga penggunaan komponen kimiawi ditekan seminimalisir bahkan meniadakan penggunaan antibiotik. Pada Gambar 5, tahun 2018 serangan BPKC sangat tinggi namun pada akhirnya mampu menunjukkan hasil pengendalian yang cukup baik dan efektif pada tahun 2020.

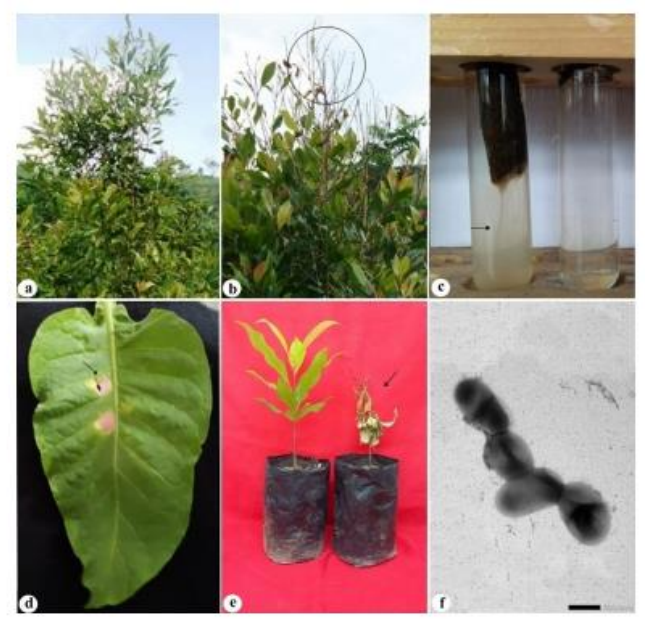

Gambar 7. a) Tanaman cengkeh yang sehat, b) tanaman cengkeh yang terserang BPKC, daun gugur, c) Reisolasi bakteri Ralstonia pada tembakau menunjukkan reaksi positif, d) tanaman cengkeh di pembibitan dalam kondisi sehat (kiri) dan sakit (kanan), e) Penampang mikroskopi Ralstonia (Trianom et al., 2019).

\section{Alternatif pengendalian bakteri ramah lingkungan}

Sebagai alternatif penggunaan bakterisida antibiotik, beberapa perusahaan pestisida menggantinya dengan penggunaan campuran tembaga. Namun hal ini tidak semerta-merta menjadi solusi, karena menurut Pal et al. (2015), garam tembaga juga menimbulkan kontaminasi pada bakteri penghuni tanah, sehingga secara signifikan beberapa bakteri tanah toleran terhadap Vankomisin dan Tetrasiklin.

Selain itu, bakteri menyimpan gen yang memberikan resistensi untuk ion logam tertentu termasuk tembaga secara signifikan memiliki gen untuk resistensi antibiotik dibandingkan dengan bakteri tanpa ketahanan logam gen. Dengan demikian, dibutuhkan agens pengendali hayati yang tidak menimbulkan efek resistensi. Menurut Kusumawati \& Istiqomah, (2018), bakteri Bacillus subtilis dan Pseudomonas fluorescens memiliki potensi sebagai agens hayati untuk menghambat beberapa patogen tanaman, diantaranya rebah semai, busuk lunak, layu bakteri, dan lain-lain pada banyak varietas tanaman.

Zat antibiotik yang diproduksi oleh Pseudomonas spp.

$(2,4-$ diacetylphloroglucinol/2,4-DAPG) mampu meningkatmampu meningkatkan ketahanan tanah terhadap patogen (Weller et al., 2012). Penelitian Chen et al. (2013) yang di lakukan di rumah kaca membuktikan bahwa B. subtilis memiliki sifat yang mampu menekan berbagai jenis patogen tanaman dan mampu bertahan pada kondisi lingkungan yang ekstrim. Hal ini diperkuat juga dengan penelitian Nasrun \& Nurmansyah (2016), menunjukkan bahwa formula $P$. fluorescens Pf19 dapat mengendalikan 
penyakit layu bakteri dan meningkatkan pertumbuhan dan produksi tanaman nilam di lapangan. B. subtilis dan $P$. fluorescens dapat menekan pertumbuhan Ralstonia solanacearum hingga $60 \%$ (Kusumawati \& Istiqomah, 2018). Selain menggunakan mikroba hayati, senyawa polifenol Resveratrol dan Coumerin yang diekstrak dari akar tanaman anggur merah, kacang, atau buah beri terbukti dapat menghambat perkembangan $R$. solanacearum pada tembakau (Chen et al., 2016). Suksesnya pengendalian tidak lepas dari penerapan budidaya tanaman yang baik (Good Agricultural Practices/GAP) dengan menciptakan kondisi lahan yang supresif, yaitu lahan yang memiliki kapasitas mencegah dan menekan penyakit antara lain dengan sanitasi lahan dari gulma yang dapat menjadi inang alternatif patogen, serta mengelola tanah secara organik dengan pemberian kompos dan mikroba yang meningkatkan kesuburan tanah (Rahayu, 2015). Mekanisme supresifitas tanah organik tersebut belum diketahui secara pasti, tetapi terdapat dugaan bahwa supresifitas berkaitan dengan peningkatan komunitas mikroba agens hayati dalam tanah sehingga perkembangan bakteri layu menjadi terhambat (Rahayu, 2015).

\section{KESIMPULAN}

Data penggunaan antibiotik pada tanaman yang tersaji secara global maupun di Indonesia masih sangat terbatas. Merujuk pada informasi penggunaan antibiotik pada perkebunan yang diperkirakan penggunaan terakhir pada tahun 2013, maka diduga residu antibiotik telah terdegradasi di tanah. Namun beberapa kemungkinan ini perlu dibuktikan secara empiris, dan diperlukan kajian lebih lanjut dan rinci dengan melibatkan peran banyak pihak dari berbagai multi sektor. Beberapa langkah yang dapat ditempuh sebagai berikut:

1. Penerapan seleksi ketat terhadap pendaftaran pestisida berbahan aktif antibiotik

2. Pengawasan peredaran dan penggunaan pestisida berbahan aktif antibiotik di lapangan

3. Pengambilan sampel tanaman dan atau tanah untuk mengetahui residu yang tertinggal pada produk

4. Pengujian resistensi antibiotik pada penyakit tanaman

5. Pendampingan petani dalam melakukan pengendalian penyakit secara terpadu

Pengaruh buruk antibiotik pada tanaman ke manusia maupun hewan lebih besar pada produk pertanian sebagai pangan konsumsi langsung, 
sehingga risiko pada tanaman perkebunan cenderung lebih rendah. Selain itu untuk menghindarkan adanya residu pada produk tanaman perlu diperhatikan Post Harvest Interval (PHI) yaitu periode waktu antara waktu terakhir aplikasi dan waktu panen.

Prinsip Pengendalian Hama Terpadu (PHT), atau secara global dikenal dengan Integrated Pest Management (IPM) harus tetap ditekankan untuk meminimalisir residu dan menghindari terjadinya resistensi antibiotik dengan penggunaan beberapa mikroba hayati dan ekstrak tumbuhan. Selain itu penerapan budidaya yang baik (Good Agricultural Practices/GAP) dengan menciptakan kondisi pertanaman yang kondusif agar tidak optimal untuk pertumbuhan dan perkembangan patogen merupakan kunci sukses menghindarkan Isu AMR.

\section{DAFTAR PUSTAKA}

[DITJEN PSP]. Direktorat Jenderal Prasarana dan Sarana Pertanian. (2021). Sistem informasi Pestisida. Direktorat Pupuk dan Pestisida (pestisida.id).

URL:

http://pestisida.id/simpes app/index .php. (diakses pada 10 September 2021).

[DITLINBUN]. Direktorat Perlindungan Perkebunan. (2021). Sistem Pelaporan dan Rekapitulasi Data OPT
(SiPeReDa). sipereda.ditjenbun.pertanian.go.id.

[KEMENKES]. Kementerian Kesehatan. (2015). Penggunaan antibiotik bijak dan rasional kurangi beban penyakit infeksi.URL:https://www.kemkes.go.i d/article/view/15081100001/pengg unaan-antibiotik-bijak-dan-rasionalkurangi-beban-penyakit-infeksi.html. (diakses pada 15 September 2021).

Chen, J., Yu, Y., Li, S., \& Ding, W. (2016). Resveratrol and coumarin: Novel agricultural antibacterial agent against Ralstonia solanacearum in vitro and in vivo. Molecules 21. https://doi.org/10.3390/molecules21 111501

Chen, Y., Yan, F., Chai, Y., Liu, H., Kolter, R., Losick, R., \& Guo, J. (2013). Biocontrol of tomato wilt disease by Bacillus subtilis isolates from natural environments depends on conserved genes mediating biofilm formation. Environmental Microbiology, 15(3), 848-864. doi: 10.1111/j.14622920.2012.02860.x

Dall, C. (2020). Study questions antibiotic recommendations for crops. URL: https://www.cidrap.umn.edu/newsperspective/2020/06/studyquestions-antibioticrecommendations-crops. (diakses pada 2 Oktober 2021).

FAO \& WHO. 2015. Codex Alimentarius: Codes texts of foodborne antimicrobial resistance. Rome, FAO and Geneva, WHO. 223 pp. URL: http://www.fao.org/3/a-i4296t.pdf. (diakses pada 2 Oktober 2021).

Hariyadi, BW. (2017). Analisis kehilangan hasil pada tanaman cengkeh akibat serangan bakteri pembuluh kayu cengkeh (BPKC) studi kasus di Kecamatan Wonosalam Kabupaten Jombang. $J$ Gontor AGROTECH Science, 3 (1), Juni 2017 DOI: $\quad 10.21111$ /agrotech.v3i1.899. URL: http://ejournal.unida.gontor.ac.id/ind 
ex.php/agrotech. (diakses 15 Oktober 2021).

Hidayanti, E., \& Yuniari, F. (2013). Perkembangan serangan penyakit bakteri pembuluh kayu cengkeh (BPKC), Pseudomonas syzygii di Provinsi Jawa Timur. URL: adoc.pub_perkembangan-seranganpenyakit-bakteri-pembuluh-ka.pdf (diakses pada 4 Oktober 2021).

Jacobs, A. (2019). Citrus Farmers Facing Deadly Bacteria Turn to Antibiotics, Alarming Health Ofcials-The New York Times. The New York Times. URL: $\quad$ https:// www.nytimes.com/2019/05/17/heal th/antibiotics-oranges-forida.html. (diakses pada 18 Oktober 2021).

Kurenbach, B., Hill, AM., Godsoe, W., Van Hamelsveld, S., \& Heinemann, JA. (2018). Agrichemicals and antibiotics in combination increase antibiotic resistance evolution. PeerJ, 6(10), e5801.

Kusumawati, DE., \& Istiqomah. (2018). Pemanfaatan Bacillus subtilis dan Pseudomonas fluorescens dalam pengendalian hayati Ralstonia solanacearum penyebab penyakit layu bakteri pada tomat. Jurnal Agro, 5(1), 2018.

Mardiningsih, TL., et al. (2020). Control of Xylem Limited Bacterium (XLB) disease of clove and its insect vector with biocontrol agents. IOP Conf. Ser.: Earth Environ. Sci. 468012038

Masnilah, R., \& Pradana, AP. (2019). Penyakit pada tanaman tembakau dan teknik pengendaliannya. Univ.Jember. URL: Penyakit Pada Tanaman Tembakau dan Teknik Pengendaliannya (slideshare.net). (diakses pada 7 Oktober 2021)

McManus, PS. (2014). Does a drop in the bucket make a splash? Assessing the impact of antibiotic use on plants. $J$ Curr Opin Microbiol, 19(1):76-82.
Nasrun \& Nurmansyah. (2016). Keefektifan formula Pseudomonas fluorescens untuk mengendalikan penyakit layu bakteri dan meningkatkan pertumbuhan tanaman nilam. J Perhimpunan Fitopatologi Indonesia, 12(2), 46-52 DOI: 10.14692/jfi.12.2.46.

O'Neill J. (2015). Antimicrobials in agriculture and the environment: reducing unnecessary use and waste. URL: http://amrreview.org/sites/default/fles/Antim icrobialsinagricultureandtheenvironm ent-Reducingunnecessaryuseand waste.pdf. (diakses pada 18 Oktober 2021).

Pal, C., Bengtsson-Palme, J., Kristiansson, E., \& Larsson, DGJ. (2015). Cooccurrence of resistance genes to antibiotics, biocides and metals reveals novel insights into their coselection potential. J BMC Genomics 16(1):964.

Rahayu M. (2015). Penyakit layu bakteri bioekologi dan cara pengendaliannya. URL:

https://balitkabi.litbang.pertanian.go. id/wpcontent/uploads/2015/06/16. OK m udjiOK 284-305-1.pdf. (diakses pada 18 Oktober 2021).

Raini, M. (2015). Kajian pestisida berbahan aktif antibiotika. Media Litbangkes, 25(1), $33-42$.

Rivero-Menendez, $\quad 0, \quad$ AlastrueyIzquierdo, A., Mellado, E. \& CuencaEstrella, M. (2016). Triazole resistance in Aspergillus spp.: A worldwide problem? Journal of Fungi, 2(3): 21. DOI 10.3390/jof2030021.

Stockwell, \& Duffy, B. (2012). Use of antibiotics in plant agriculture. Rev. sci. tech. Off. int. Epiz., 31(1), 199-210.

Sundin, GW. \& Wang, N. (2019). Annual review of phytopathology antibiotic resistance in plant-pathogenic bacteria. URL: Antibiotic Resistance in 
Plant-Pathogenic Bacteria (stopamr.eu). (diakses pada 15 Oktober 2021).

Taylor, P., \& Reeder, R. (2020). Antibiotic use on crops in low and middleincome countries based on recommendations made by agricultural advisors. J CABI Agric Biosci 1:1

https://doi.org/10.1186/s43170020-00001-y.

Trianom, B., Arwiyanto, W., \& Joko, T. (2019). Morphological and molecular characterization of Sumatra Disease of clove in Central Java, Indonesia. URL: https://www.researchgate.net/public ation/331062245 Morphological and Molecular Characterization of Sumat ra Disease of Clove in Central Java I ndonesia. (diakses pada 29 September 2021).

Utami, ER. (2012). Antibiotika, resistensi, dan rasionalitas terapi. URL: ejournal.uin-

malang.ac.id/index.php/sainstis/artic le/view/1861. (diakses pada 10 Oktober 2021)

Wan $\mathrm{M}, \mathrm{Gu} \mathrm{R}$, Zhang $\mathrm{T}$, Zhang $\mathrm{Y}$, Ji $\mathrm{H}$, Wang B, et al. (2019). Conficts of interests when connecting agricultural advisory services with agri-input businesses. Agriculture. 9(10):218.

Weller, D. M., Mavrodi, D. V, van Pelt, J. A., Pieterse, C. M. J., van Loon, L. C., \& Bakker, P. A. H. M. (2012). Induced systemic resistance in Arabidopsis thaliana against Pseudomonas syringae pv. tomato by 2, 4diacetylphloroglucinol-producing Pseudomonas fluorescens. Phytopathology, 102(4), 403-412. https://doi.org/10.1094/PHYTO-0811-0222. 